\title{
Decreased skeletal muscle phosphotyrosine phosphatase (PTPase) activity towards insulin receptors in insulin-resistant Zucker rats measured by delayed Europium fluorescence
}

\author{
D. Worm ${ }^{1}$, A. Handberg ${ }^{2}$, E.Hoppe ${ }^{3}$, J. Vinten ${ }^{2}$, H. Beck-Nielsen ${ }^{1}$ \\ ${ }^{1}$ Diabetes Research Centre and Department of Endocrinology, Odense University Hospital, Odense, Denmark \\ ${ }^{2}$ Department of Medical Physiology, Panum Institute, University of Copenhagen, Copenhagen, Denmark \\ ${ }^{3}$ Abteilung für Molekulare Biologie, Max Planck Institut für Biochemie, Martinsried, Germany
}

Summary In order to measure the phosphotyrosine phosphatase (PTPase) activity in small muscle biopsies, a sandwich-immunofluorescence assay was developed using the phosphorylated human insulin receptor as a substrate, a C-terminal insulin receptor antibody as catching antibody and Europium-labelled anti-phosphotyrosine as detecting antibody. Soluble and particulate muscle fractions were prepared from soleus muscle of obese, diabetic (fa/fa) Zucker rats and their lean littermates $(\mathrm{Fa} /-)$. In the soluble muscle fractions of the obese (fa/fa) rats PTPase activity was significantly reduced compared to control $(\mathrm{Fa} /-)$ rats $(45.2 \pm 2.6 \%$ vs $61.3 \pm 4.7 \%$, $p<0.02)$. This reduction was completely prevented by 24 days of metformin treatment which decreased plasma glucose and plasma insulin levels. In particulate muscle fractions, however, no difference in PTPase activity was found among any groups of rats examined. These results show that the alterations in soluble PTPase activity in the insulin-resistant, diabetic Zucker rat vary with the abnormality in glucose homeostasis. [Diabetologia (1996) 39: 142-148]

Key words Insulin receptor, phosphotyrosine phosphatases, insulin resistance, skeletal muscle, Zucker rats, metformin.
Phosphorylation of protein tyrosyl residues plays an important role in intracellular signalling, initiated by insulin and growth factors $[1,2]$. The tyrosyl phosphorylation level of a protein in a signal transduction chain reflects a balance between activities of more or less specific phosphotyrosine kinases and phosphatases $[1,3]$. The phosphotyrosine phosphatases (PTPases) can be subdivided into two classes: a group of higher molecular weight, transmembrane, receptorlike enzymes and a group of cytosolic enzymes of lower molecular weight [3]. PTPase activity has been

Received: 6 June 1995 and in revised form: 14 July 1995

Corresponding author: Dr. D. Worm, Department of Endocrinology, Odense University Hospital, Sdr. Boulevard, DK5000 Odense C, Denmark

Abbreviations: PMSF, Phenyl methyl sulphonyl-fluoride; PTPase, phosphotyrosine phosphatase; BHK, baby hamster kidney; RCM-lysozyme, reduced, carboxyamidomethylated, and maleylated lysozyme; Hepes, 4-(2-hydroxyethyl)-l-piperazineethane sulphonic acid. found in various tissues of the organism, including skeletal muscle [4-7], an important target organ for insulin.

Insulin acts by binding to a specific receptor and induces autophosphorylation of tyrosyl residues of the receptor $\beta$-subunit, increasing the activity of the insulin receptor tyrosine kinase $[8,9]$. In several studies of insulin-resistant animal models and in insulinresistant human subjects a decreased insulin receptor tyrosine kinase activity in muscle has been found [1013].

Insulin receptor signalling could be counteracted by PTPases dephosphorylating the insulin receptor, insulin receptor substrates or tyrosine-phosphate intermediates further downstream in the insulin-signalling cascade. Thus, PTPases could control the amplification in the insulin-signalling chain.

PTPase activity in insulin-responsive tissues has been measured with different substrates and different models of insulin resistance, giving conflicting results $[4-7,14-18]$. The aim of the present study was, using 
phosphorylated human insulin receptors as the substrate, to measure PTPase activity in insulin-resistant skeletal muscle fractions with an improved technique.

As a model of insulin resistance in skeletal muscle we used the well-characterized adult obese Zucker rat (fa/fa) which displays severe fasting hyperinsulinaemia, moderate hyperglycaemia, glucose intolerance and an elevated plasma insulin response to a glucose challenge [19-21]. In Zucker rats the insulin receptor tyrosine kinase activity as well as autophosphorylation in skeletal muscle have been described as unchanged [22] or decreased [23] compared to lean controls.

To corroborate that changes in PTPase activities in the Zucker rats were related to insulin resistance, we extended the model to include Zucker rats treated with the anti-diabetic drug metformin (N,N-dimethylbiguanide) [24-26].

\section{Materials and methods}

Materials. Dithiothreitol, 4-(2-hydroxyethyl)-1-piperazineethane sulphonic acid (Hepes) ATP, Triton X-100, N-acetyl-Dglucosamine, bovine serum albumin, sodium-ortho-vanadate $\left(\mathrm{Na}_{3} \mathrm{VO}_{4}\right)$, benzamidine, leupeptin and phenyl methyl sulphonyl-fluoride (PMSF) were from Sigma (St. Louis, Mo., USA). Trasylol was obtained from Bayer (Leverkusen, Germany) and EDTA and magnesium chloride were from Merck (Darmstadt, Germany). Agarose wheat germ lectin was from Pharmacia (Piscataway, N.J., USA) and Dulbecco's modified Eagle's medium (without sodium pyruvate, with $4500 \mathrm{mg} / \mathrm{l}$ glucose), fetal calf serum, trypsin, penicillin and glutamine were provided by Gibco BRL, Life Technologies Ltd. (Paisey, Scotland, UK). Bradford protein assay was from Bio-Rad Laboratories GmbH (München, Germany). Europium kit, DELFIA assay-buffer and enhancement-buffer were obtained from Wallac (Turku, Finland). Micro-titre wells were from Nunc (Copenhagen, Denmark). Monoclonal antibody to the $\beta$-subunit of the insulin receptor, CT1, was a generous gift from Dr. K. Siddle. Polyclonal anti-phosphotyrosine-antibody from Zymed Laboratories San Francisco Calif., USA) was Europium-labelled as described in the Wallac Europium-labelling kit giving $1.5 \mathrm{~mol} \mathrm{Eu}^{3+} / \mathrm{mol}$ antibody. Phosphatase $1 \mathrm{~B}$ was purified in Dr. A. Ullrich's laboratory, Martinsried, München, Germany. Baby hamster kidney cells (BHK cells) overexpressing the human insulin receptor were kindly donated by Novo Nordisk (Bagsværd, Denmark).

Preparation of particulate and soluble fractions from soleus muscle. Rat soleus muscles were obtained from Zucker rats $(\mathrm{fa} / \mathrm{fa})$ and their lean littermates $(\mathrm{Fa} /-)$. The soleus muscles were saved from an earlier study [27] in which 14 obese male Zucker rats and 14 lean littermates from Charles River Laboratories (Cambridge, Mass., USA) were kept on an artificial 12-h day-night cycle at $21^{\circ} \mathrm{C}$ and given free access to food. Seven obese Zucker rats and seven lean control rats were chosen randomly for treatment with metformin ingested by means of a gastric tube according to the following scheme: $90 \mathrm{mg} /$ day for 6 days, $180 \mathrm{mg} /$ day for 6 days, $225 \mathrm{mg} /$ day for 6 days and $270 \mathrm{mg} /$ day for 6 days. The remaining 14 rats were treated with vehicle $(0.9 \% \mathrm{NaCl})$. The last dose of metformin or vehi-
Table 1. Characteristics of rats used in the study

\begin{tabular}{|c|c|c|c|c|}
\hline & \multicolumn{2}{|c|}{ Control $(\mathrm{Fa} /-)$ rats } & \multicolumn{2}{|c|}{ Obese (fa/fa) rats } \\
\hline & Metformin & + & Metformin & + \\
\hline $\begin{array}{l}n \\
\text { Start }\end{array}$ & 7 & 6 & 7 & 5 \\
\hline Weight (g) & $278 \pm 10$ & $275 \pm 10$ & $348 \pm 18$ & $394 \pm 28$ \\
\hline End & & & & \\
\hline Weight (g) & $342 \pm 11^{\mathrm{a}}$ & $329 \pm 12$ & $482 \pm 10$ & $523 \pm 22$ \\
\hline $\begin{array}{l}\text { Fasting plasma } \\
\text { glucose }(\mathrm{mmol} / \mathrm{l})\end{array}$ & $6.4 \pm 0.3^{\mathrm{b}}$ & $6.6 \pm 0.3$ & $12.7 \pm 1.0^{c}$ & $8.9 \pm 1.0$ \\
\hline $\begin{array}{l}\text { Fasting plasma } \\
\text { insulin }(\mathrm{pmol} / \mathrm{l})\end{array}$ & $467 \pm 100^{d}$ & $267 \pm 83$ & $1817 \pm 450^{\mathrm{c}}$ & $983 \pm 17$ \\
\hline
\end{tabular}

Data are shown as mean $\pm \mathrm{SEM}$

${ }^{\mathrm{a}} p<0.001 ;{ }^{\mathrm{b}} p<0.002 ;{ }^{\mathrm{d}} p<0.01$ vs untreated fa/fa rats; ${ }^{c} p<0.05$ vs fa/fa rats treated with metformin

cle was given $24 \mathrm{~h}$ before the start of the study. After an overnight fast the rats were anaesthetized with pentobarbital sodium $(50 \mathrm{mg} / \mathrm{kg}$ body weight i.p.) and weighed. Blood samples were taken for analysis of glucose and insulin and soleus muscles were excised and immediately frozen in $n$-hexane and stored at $-80^{\circ} \mathrm{C}$ until analysis. Three rats died during treatment, probably due to lesions from the gastric tube. In Table 1 the number of rats in each of the four groups, the weight $(\mathrm{g})$ before and after the treatment period, the fasting plasma glucose $(\mathrm{mmol} / \mathrm{l})$ and the fasting plasma insulin (pmol/l) levels after the treatment period are given.

Frozen muscle biopsies $(16-70 \mathrm{mg}$ ) were homogenized for $30 \mathrm{~s}$ on ice in $500 \mu \mathrm{l}$ homogenization buffer $(50 \mathrm{mmol} / 1$ Hepes, $200 \mathrm{mmol} / 1 \mathrm{NaCl}, 4 \mathrm{mmol} / \mathrm{l}$ dithiothreitol, $1 \mathrm{mmol} / \mathrm{l} \mathrm{PMSF}$, $100 \mu \mathrm{mol} / \mathrm{l}$ benzamidine, $100 \mu \mathrm{g} / \mathrm{ml}$ leupeptin, and $350 \mathrm{kal}-$ likrein inhibitor units/ml Trasylol, $\mathrm{pH} 7.8$ ), using a Polytron homogenizer on maximum setting. The homogenates were centrifuged at $110000 \mathrm{~g}$ for $30 \mathrm{~min}$ at $4^{\circ} \mathrm{C}$. The supernatants (soluble fractions, expected to contain cytosolic PTPases) were collected, supplemented with Triton X-100 to $0.5 \%$ and frozen immediately in liquid nitrogen. The pellets were homogenized for $30 \mathrm{~s}$ on ice in the presence of $0.5 \%$ Triton X-100 in the homogenization buffer. After centrifugation $(110000 \mathrm{~g}$ for $30 \mathrm{~min}$ at $4^{\circ} \mathrm{C}$ ), the supernatants (particulate fractions, expected to contain membrane-bound PTPases) were retained and frozen in liquid nitrogen. The protein concentration in the samples of soluble and particulate fractions was determined by the Bradford protein assay [28] using BSA as standard. Subsequently, the remaining muscle fractions for PTPase assay were diluted with the homogenization buffer supplemented with $0.5 \%$ Triton to identical protein concentrations, $1.06 \mathrm{mg} / \mathrm{ml}$ and $0.37 \mathrm{mg} / \mathrm{ml}$ in the soluble and particulate fractions, respectively, prior to analysis of PTPase activity.

Measurement of PTPase activity towards the human insulin receptor by delayed Europium fluorescence. Titre plate wells were coated with a mouse monoclonal antibody $(1.1 \mathrm{ug}$ protein $/ \mathrm{ml}, \mathrm{pH} 8.0,50 \mathrm{mmol} / 1 \mathrm{~K}_{2} \mathrm{PO}_{4}, 100 \mu \mathrm{l} /$ well) against the $\beta$ subunit of the human insulin receptor, CT1 $[29,30]$, for $1 \mathrm{~h}$ at room temperature and blocked with a $0.5 \%$ albumin-buffer. Human insulin receptors were prepared from $1 \%$-Triton lysates of BHK cells expressing about $5 \times 10^{6}$ receptors per cell (Finn Wiberg, Novo Nordisk). The insulin receptors in $3 \mathrm{ml}$ lysate (about $50 \times 10^{6}$ cells) were bound to wheat germ agglutinin immobilized on agarose beads $(0.32 \mathrm{mg}$ wheat germ agglutinin in $1 \mathrm{ml}$ buffer $(50 \mathrm{mmol} / 1$ Hepes, $150 \mathrm{mmol} / 1 \mathrm{NaCl}$, $0.1 \%$ Triton $\mathrm{X}-100)$ ) by incubation overnight at $4{ }^{\circ} \mathrm{C}$ in a rotat- 
ing mixer. N-acetyl-D-glucosamine $(0.3 \mathrm{~mol} / \mathrm{l})$ in buffer (50 mmol/1 Hepes, $150 \mathrm{mmol} / 1 \mathrm{NaCl}, 0.1 \%$ Triton X-100) was used for elution. Following elution the receptors were phosphorylated for $1 \mathrm{~h}$ at room temperature in the presence of $1 \mathrm{mmol} / \mathrm{l} \mathrm{ATP}, 10 \mathrm{mmol} / \mathrm{l}$ magnesium chloride and $100 \mathrm{nmol} / \mathrm{l}$ insulin. The reaction was stopped by $12 \mathrm{mmol} / \mathrm{l}$ EDTA and $\mathrm{pH}$ was adjusted to 7.8. The phosphorylated receptor preparation was added to the CT1-coated wells (dilution 1:4, $100 \mu \mathrm{l} /$ well) and incubated overnight at room temperature. After six washes (referred to as washing) wells were incubated for $2 \mathrm{~h}$ with soluble and particulate muscle fractions ( $53 \mu \mathrm{g}$ protein/ well and $18 \mu \mathrm{g}$ protein/well, respectively). After washing, Europium-labelled anti-phosphotyrosine antibody was added $(0.1 \mathrm{mg} / \mathrm{ml}$, diluted 1:500 in DELFIA assay-buffer, $100 \mu \mathrm{l} /$ well) and incubated for $2 \mathrm{~h}$. This was followed by washing of the wells. After addition of enhancement-solution, delayed fluorescence of Europium was measured using a 1234 DELFIA Research Fluorometer (Wallac). The decline in fluorescence, representing dephosphorylation of insulin receptor phosphotyrosylresidues after a 2-h incubation with muscle fractions, was expressed as percentage of the initial fluorescence. The initial level of fluorescence was determined following 2-h incubation of antibody-bound phosphorylated insulin receptor with muscle fractions in the presence of $10 \mathrm{mmol} / 1 \mathrm{Na}_{3} V_{4}$, which is considered to be the specific and classical PTPase inhibitor [31]. The decline in fluorescence was thereby corrected for possible non-enzymatic loss of bound phosphotyrosyl caused by, e.g., dissociation of antibody-bound phosphorylated insulin receptors from the wells. In preliminary experiments we investigated the time and concentration dependence of insulin-receptor dephosphorylation by pure PTPase $1 \mathrm{~B}$ and no further dephosphorylation of insulin receptors was found following incubation for $2 \mathrm{~h}$ with $80 \mathrm{ng}$ PTPase $1 \mathrm{~B} /$ well. The fluorescence remaining after incubation with muscle fraction supplemented with pure PTPase $1 \mathrm{~B}$ ( $80 \mathrm{ng} /$ well) was used as $100 \%$ dephosphorylation. This value never exceeded $10 \%$ of the initial fluorescence. The time course of dephosphorylation was nearly linear up to $50 \%$. The fact that some of the measurements slightly exceeded this value might give rise to an underestimation of the true difference between group mean values. We accepted this probably minor bias since our primary aim was to establish the direction of changes in rate of dephosphorylation between groups, and since estimates based on initial rates of dephosphorylation tended to be severely affected by random error. Measurements were performed in triplicate and median values were used.

\section{Statistical analysis}

Data were analysed by means of non-parametric statistical methods. For unpaired data the Mann-Whitney test was used and for paired data the Wilcoxon test was used. Spearman's rho was used for correlation, and $p$-values less than 0.05 were considered significant. Data are presented as mean \pm SEM.

\section{Results}

In Figure 1 an autoradiogram of an SDS-gel separation of $\left[\gamma^{-32} \mathrm{P}\right]$ ATP phosphorylated eluate shows the ${ }^{32} \mathrm{P}$-phosphorylation of the purified insulin receptors. It has been noted that the $\beta$-subunit $(97 \mathrm{kDa}$ ) of the insulin receptor constitutes a major part of the phosphorylated protein. Insulin receptor dephosphoryla-

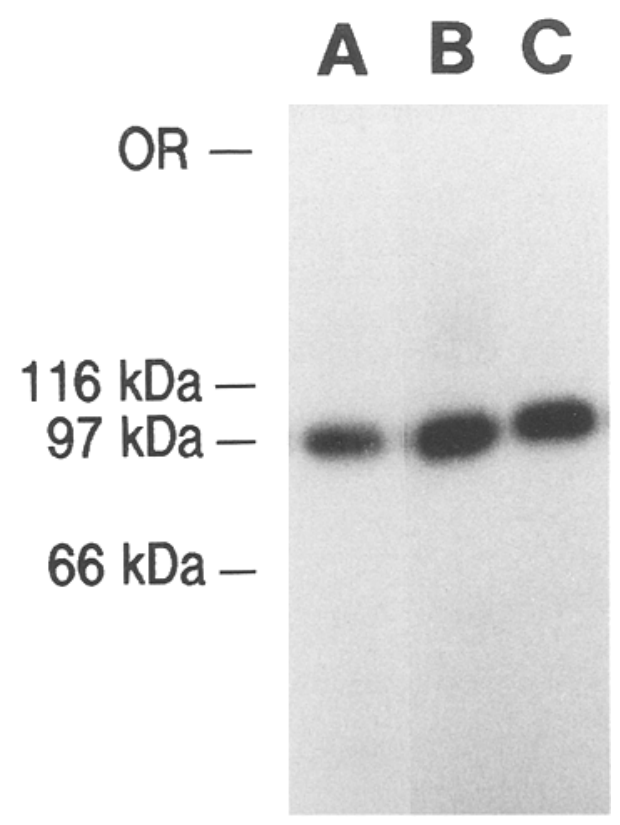

Fig. 1. Autoradiogram showing ${ }^{32} \mathrm{P}$-phosphorylation of the wheat-germ agglutinin-purified insulin receptors. Autophosphorylation of insulin receptors $(9 \mu \mathrm{g}$ protein $/ \mathrm{ml})$ was accomplished by the addition of $0.1 \mu \mathrm{mol} / 1$ insulin, $6.5 \mu \mathrm{mol} / \mathrm{l}$ ATP, $\left[\gamma-{ }^{32} \mathrm{P}\right]$ ATP $(43 \mathrm{Ci} / \mathrm{mmol})$ and $7.4 \mathrm{mmol} / 1 \mathrm{MnCl}_{2}$ in $50 \mathrm{mmol} / \mathrm{l}$ Hepes, pH 7.6, $1 \%$ Triton X-100, $4 \mathrm{mmol} / 1$ EDTA, $400 \mathrm{kal}-$ likrein inhibitor units/ml Trasylol, $1 \mathrm{mmol} / 1 \mathrm{PMSF}, 8.7 \mu \mathrm{mol} / 1$ pepstatin, $16.8 \mu \mathrm{mol} / 1$ leupeptin for $30 \mathrm{~min}$ at room temperature. Particulate fraction from normal rat soleus muscle was prepared by homogenization as described in Methods. Twenty microlitres of phosphorylated insulin receptor preparation was incubated with $80 \mu \mathrm{l}$ of particulate muscle fractions $(0.75 \mathrm{mg}$ protein $/ \mathrm{ml}$ ) without (lane A) and with $5 \mathrm{mmol} / \mathrm{l}$ $\mathrm{Na}_{3} \mathrm{VO}_{4}$ (Iane $\mathrm{B}$ ) for $20 \mathrm{~min}$. Lane $\mathrm{C}$ is control (insulin receptors incubated with buffer). Origin of $7.5 \%$ SDS-PAGE resolving gel run under reducing conditions is indicated at the upper left $(\mathrm{OR})$ and molecular masses $(\mathrm{kDa})$ of marker proteins on the left

tion by soluble and particulate fractions of soleus muscle from normal rats was nearly proportional with incubation time and protein concentration in the intervals studied (Fig. 2).

The PTPase activity in the soluble muscle fractions of the obese untreated (fa/fa) rats was significantly reduced compared to the lean untreated $(\mathrm{Fa} /-)$ controls $(45.2 \pm 2.6 \%$ vs $61.3 \pm 4.7 \%, p<0.02$, Fig. 3 ; the percentage indicates the decline in fluorescence, representing dephosphorylation of insulin receptor phosphotyrosyl residues after a 2 -h incubation with muscle fractions).

In the particulate fractions no difference between PTPase activities in obese untreated (fa/fa) rats and lean untreated $(\mathrm{Fa} /-)$ rats was found $(41.8 \pm 5.9 \%$ vs $49.4 \pm 4.1 \%$, NS, Fig. 4 ).

The reduction in PTPase activity found in the soluble muscle fractions of untreated $(\mathrm{fa} / \mathrm{fa})$ rats when compared to the PTPase activity of soluble fractions of untreated $(\mathrm{Fa} /-)$ rats was prevented in the soluble muscle fractions of metformin-treated $(\mathrm{fa} / \mathrm{fa})$ rats 

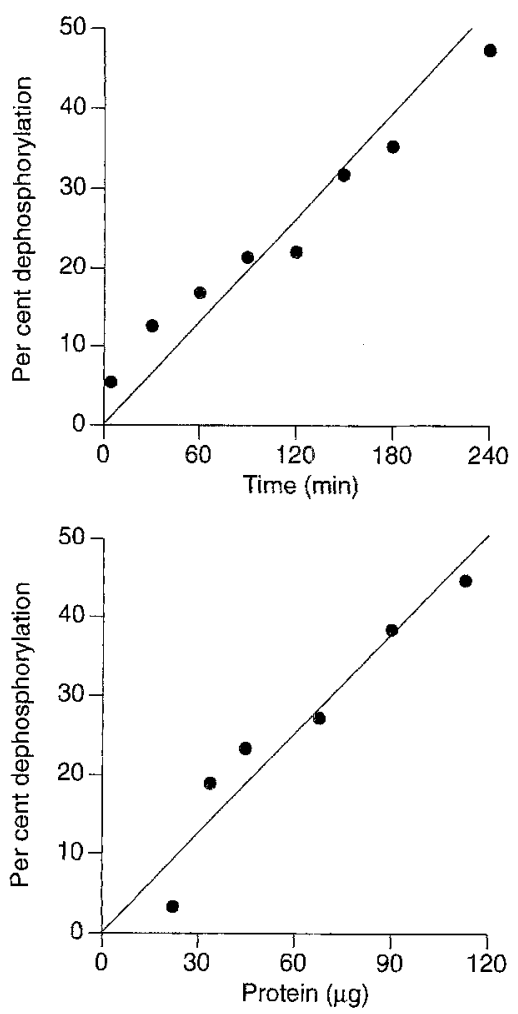

Fig. 2. Time and concentration dependence of insulin receptor dephosphorylation. Phosphorylated insulin receptors in titre wells were incubated with aliquots of a soluble muscle fraction (125 $\mu \mathrm{g}$ protein/well) for various times (upper panel) or for $2 \mathrm{~h}$ with various amounts ( $\mu \mathrm{g}$ protein/well) of particulate muscle fraction (lower panel) from normal rat soleus muscle

$(62.6 \pm 5.9 \%$ vs $45.2 \pm 2.6 \%, p<0.05$, metformintreated fa/fa rats vs untreated fa/fa rats, Fig. 3 ).

In the rats we studied, protein recovery from soleus muscles was highest in the soluble fractions. The highest specific PTPase activity (defined as per cent dephosphorylation of added phosphorylated insulin receptor per $2 \mathrm{~h}$ per $\mathrm{mg}$ muscle fraction protein) was found in the particulate fractions (all 25 rats: $44.2 \pm 3.0 \%$ vs $20.8 \pm 1.2 \%, p<0.001$, data not shown).

No correlation was found between soluble and particulate specific PTPase activities (defined as above) when the individual values of the 25 rats were compared $(r=0.09$, NS, data not shown). This indicates the absence of interdependence (caused, for instance, by variations in the intensity of homogenization) between recoveries of soluble and particulate activities.

\section{Discussion}

Most frequently, PTPase activity has been measured by release of $\left[{ }^{32} \mathrm{P}\right] \mathrm{P}_{\mathrm{i}}$ from phosphorylated proteins, using phosphotyrosine kinases and $\left[\gamma^{-32} \mathrm{P}\right]$ ATP for phosphorylation [1]. If the phosphotyrosine kinase preparation used for labelling is contaminated with

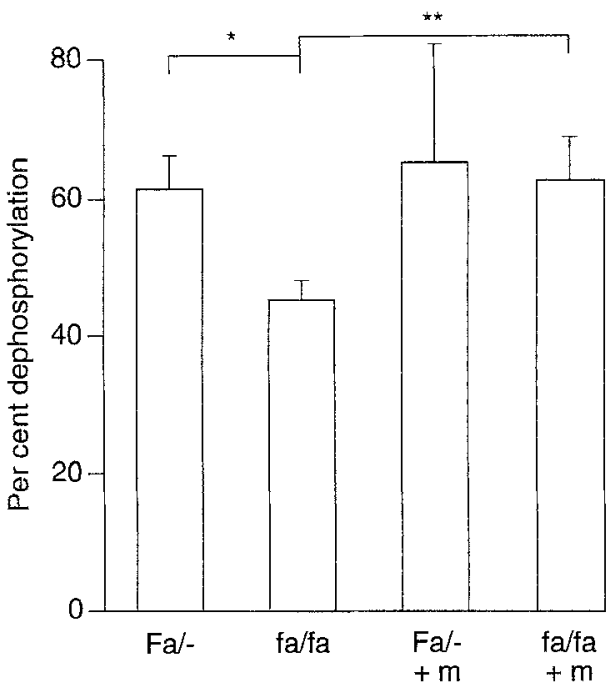

Fig. 3. PTPase activity in soluble muscle fractions from Zucker $(\mathrm{fa} / \mathrm{fa})$ rats and their lean littermates $(\mathrm{Fa} /-)$ with and without metformin (m) treatment. Fractions were adjusted to protein concentrations of $1.06 \mathrm{mg} / \mathrm{ml}$. Mean values are shown; bars denote SEM; number of rats in each group is given in Table 1; $* p<0.02, * * p<0.05$

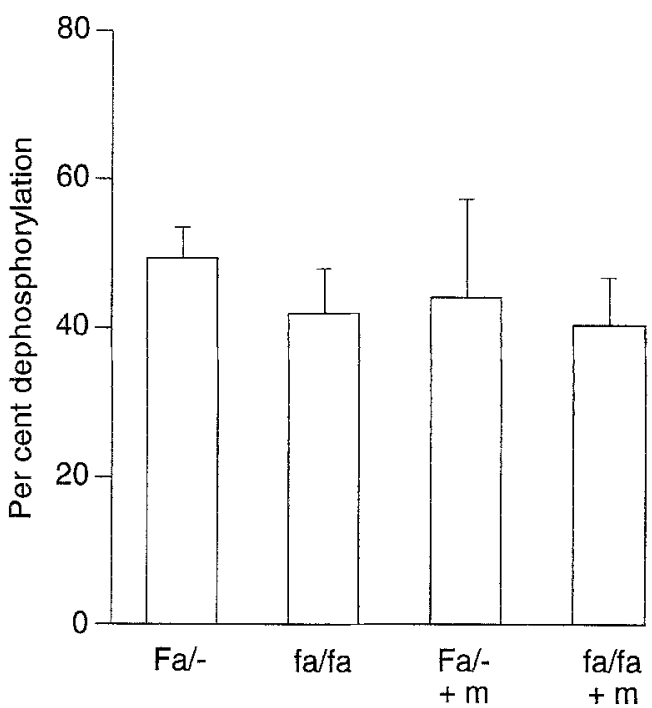

Fig.4. PTPase activity in particulate muscle fractions from Zucker (fa/fa) rats and their lean littermates ( $\mathrm{Fa} /-$ ) with and without metformin $(\mathrm{m})$ treatment. Fractions were adjusted to protein concentrations of $0.37 \mathrm{mg} / \mathrm{ml}$. Mean values are shown; bars denote SEM; number of rats in each group is given in Table 1

phosphoserine/threonine kinases, serine/threonine residues are phosphorylated as well. Such phosphorylation could also occur non-enzymatically, making it difficult or impossible to determine whether subsequently released $\left.{ }^{32} \mathrm{P}\right] \mathrm{P}_{\mathrm{i}}$ is the result of PTPase or phosphoserine phosphatase activity. In the present study anti-phosphotyrosine antibodies were used for detection of phosphotyrosyl residues and this error source was thereby eliminated. 
The 2.1-fold higher specific activity (defined as in the Results section) found in the particulate fraction compared to the soluble fraction is in agreement with results previously published [4] where a 1.5-2.8fold higher specific PTPase activity was found in particulate fractions compared to soluble fractions of liver, soleus muscle, white adipose tissue and brain using the purified insulin receptor as a substrate. Since some of the measurements were performed at the limit of linearity of our assay, an underestimation of the true differences might occur (see Methods section). This possible underestimation in the assay would not, however, interfere with non-parametric tests for differences between samples.

Recently, several authors have measured PTPase activity by means of different exogenous substrates in different tissues of both insulin-dependent and non-insulin-dependent diabetic animal models and insulin-resisant human subjects. The results do not form a uniform picture of the significance of the direction of changes in PTPase activity in insulin resistance.

Liver PTPase activity has been the most thoroughly studied. It has been reported that the overall PTPase activity was increased in livers of streptozotocin-diabetic rats using a synthetic peptide as a substrate [14]. Gruppuso et al. [15] found a decreased PTPase activity in both soluble and particulate liver fractions in alloxan-diabetic rats only when the insulin receptor was used as a substrate and not when the substrate was RCM-lysozyme (reduced, carboxyamidomethylated, and maleylated lysozyme) or polyglutamic acid:tyrosine 4:1 emphasizing the importance of the substrate for the PTPase activity. A decreased hepatic PTPase activity was found in particulate and soluble fractions of ob/ob mice and in soluble fractions of $\mathrm{db} / \mathrm{db}$ mice when a synthetic peptide containing the amino acid sequence between residues 1142 and 1153 of the insulin receptor $\beta$-subunit was used as a substrate [16]. Begum et al. [5] found an increased cytosolic and membrane-associated PTPase activity in livers of streptozotocin-diabetic rats, using the insulin receptor as a substrate. An increased PTPase activity in a particulate fraction of liver was described in alloxan-diabetic rats only when myelic basic protein was the substrate, whereas no difference was detected with other substrates (RCM-lysozyme and the insulin receptor tyrosine kinase domain) [17]. Hauguel-de Mouzon et al. [4] found a 40-50\% decrease in PTPase activity measured by means of exogenous insulin receptors in a liver particulate fraction from streptozotocin diabetic rats. No difference in either membranebound or cytosolic PTPase activity was detected when liver from gold-thioglucose-treated mice was used [6].

Skeletal muscle studies have produced results which are as conflicting as those obtained from liver studies. McGuire et al. [7] measured particulate and soluble PTPase activity in muscle biopsies from insulin-resistant and insulin-sensitive human subjects with RCM-lysozyme as a substrate. This group was the first to characterize PTPase activity in insulin-resistant patients. In fasting insulin-resistant subjects they found a $33 \%$ increase in PTPase activity in the particulate fractions [7]. These initial findings are at variance with the results of a study on a larger number of subjects where a reduction of $21 \%$ and $22 \%$ was found in particulate skeletal muscle fractions from obese non-diabetic and non-insulin-dependent diabetic patients, respectively. In the latter study, a synthetic peptide (1142-1153) was used as the substrate [18].

In the soluble fraction of hindleg muscle of goldthioglucose-treated mice Olichon-Berthe et al. [6] found decreased PTPase activity measured by means of exogenous insulin receptors. In the present study of soluble soleus muscle fractions from insulin-resistant Zucker rats we found a decreased PTPase activity, using the human insulin receptor as a substrate. These results agree and in addition our model comprises a group of Zucker rats in which parameters used as indicators of insulin resistance were partially reversed by metformin treatment as was the PTPase activity.

The decrease in PTPase activity in the soluble fractions in these insulin-resistant animal models could be explained as the product of a compensatory mechanism ameliorating insulin resistance (see below). A decreased PTPase activity is expected to increase the tyrosine phosphorylation and thus increase insulin signalling.

It is not known whether a PTPase exists which acts exclusively on the phosphorylated insulin receptor or also on other phosphorylated proteins in the insulin induced signal chain. However, it has been shown that the soluble PTPase 1D (also known as PTP2C, SH-PTP2 and Syp) contains two Src homology 2 (SH2) domains [32], and that these $\mathrm{SH} 2$ domains bind to phosphorylated tyrosine residues of IRS-1 (insulin receptor substrate 1) [33,34]. PTPase 1D rapidly dephosphorylates phosphotyrosyl-IRS-1, and will thereby attenuate signalling from phosphotyrosyl-IRS-1. The insulin signalling cascade is presumed to irradiate from IRS-1 to several chains eliciting different effects. If stimulation of one of these signal chains increased the level of expression of PTPase $1 D$ or other PTPases with activity towards intermediates in the insulin signalling chain, this could constitute a long-term negative feed-back mechanism controlling the early intracellular insulin signal amplification. As an alternative to a lowered expression level of PTPases, a decrease in soluble PTPase activity could be accomplished by association of PTPases with the cytoskeleton. However, two studies on PTPase activity in the cytoskeleton of liver preparations 
report no difference between alloxan-diabetic rats and controls $[15,17]$.

The hypoglycaemic drug, metformin, is used in the treatment of non-insulin-dependent diabetic patients. Several anti-diabetic effects of metformin have been described [24, 35-40] including an increase of glucose uptake in peripheral tissues (fat and muscle) [38-40]. We found that the decreased PTPase activity was abolished in the soluble muscle fractions of the Zucker rats after metformin treatment. If PTPases constitute part of a cellular feedback amplification control as suggested above, the observed increase in PTPase activity following metformin treatment could be the result of a primary, metformin-induced increase in insulin signalling.

In conclusion, we have found a reversibly-decreased PTPase activity in soluble soleus muscle fractions which may represent a futile compensation of the insulin resistance present in skeletal muscle of Zucker rats.

Acknowledgements. We are very grateful to Director A. Ullrich for letting the initial experiments take place in his laboratory at the Max Planck Institute, Martinsried, and for providing materials. The expert technical assistance of Ms. U. Blankensteiner and Ms. J. Harp $\varnothing$ th is acknowledged. The study was supported financially by the Danish Diabetes Association and the Clinical Research Institute, Odense University Hospital.

\section{References}

1. Lau KHW, Farley JR, Baylink DJ (1989) Phosphotyrosyl protein phosphatases. Biochem J 257: 23-36

2. Schlessinger J, Ullrich A (1992) Growth factor signalling by receptor tyrosine kinases. Neuron 9: 383-391

3. Fischer EH, Charbonneau H, Tonks NK (1991) Protein tyrosine phosphatases: a diverse family of intracellular and transmembrane enzymes. Science 253: 401-406

4. Hauguel-de Mouzon S, Peraldi P, Alengrin F, Van Obberghen $E$ (1993) Alteration of phosphotyrosine phosphatase activity in tissues from diabetic and pregnant rats. Endocrinology 132: 67-74

5. Begum N, Sussman KE, Draznin B (1991) Differential effects of diabetes on adipocytes and liver phosphotyrosine and phosphoserine phosphatase activities. Diabetes 40 : 1620-1629

6. Olichon-Berthe C, Hauguel-de Mouzon S, Péraldi P, Van Obberghen E, Le Marchand-Brustel Y (1994) Insulin receptor dephosphorylation by phosphotyrosine phosphatases obtained from insulin-resistant obese mice. Diabetologia 37: 56-60

7. McGuire MC, Fields RM, Nyomba BL et al. (1991) Abnormal regulation of protein tyrosine phosphatase activities in skeletal muscle of insulin-resistant humans. Diabetes 40 : 939-942

8. Ullrich A, Schlessinger J (1990) Signal transduction by receptors with tyrosine kinase activity. Cell 61: 203-212

9. Rosen OM, Herrera R, Olowe Y, Petruzzelli LM, Cobb MH (1983) Phosphorylation activates the insulin receptor tyrosine kinase. Proc Natl Acad Sci USA 80: 32373240

10. Le Marchand-Brustel Y, Grémeaux T, Ballotti R, Van Obberghen $\mathrm{E}$ (1985) Insulin receptor tyrosine kinase is defec- tive in skeletal muscle of insulin-resistant obese mice. $\mathrm{Na}$ ture 315: 676-679

11. Caro JF, Sinha MK, Raju SM et al. (1987) Insulin receptor kinase in human skeletal muscle from obese subjects with and without non-insulin dependent diabetes. J Clin Invest 79: $1330-1337$

12. Arner P, Pollare T, Lithell H, Livingston JN (1987) Defective insulin receptor tyrosine kinase in human skeletal muscle in obesity and type 2 (non-insulin-dependent) diabetes mellitus. Diabetologia 30: 437-440

13. Obermaier-Kusser B, White MF, Pongratz DE et al. (1989) A defective intramolecular autoactivation cascade may cause the reduced kinase activity of the skeletal muscle insulin receptor from patients with non-insulin-dependent diabetes mellitus. J Biol Chem 264: 9497-9504

14. Meyerovitch J, Backer JM, Kahn CR (1989) Hepatic phosphotyrosine phosphatase activity and its alterations in diabetic rats. J Clin Invest 84: 976-983

15. Gruppuso PA, Boylan JM, Posner BI, Faure R, Brautigan DL (1990) Hepatic protein phosphotyrosine phosphatase. Dephosphorylation of insulin and epidermal growth factor receptors in normal and alloxan diabetic rats. J Clin Invest 85: $1754-1760$

16. Meyerovitch J, Rothenberg P, Shechter Y, Bonner-Weir S, Kahn CR (1991) Vanadate normalizes hyperglycemia in two mouse models of non-insulin-dependent diabetes mellitus. J Clin Invest 87: 1286-1294

17. Boylan JM, Brautigan DL, Madden J, Raven T, Ellis L, Gruppuso PA (1992) Differential regulation of multiple hepatic protein tyrosine phosphatases in alloxan diabetic rats. J Clin Invest 90: 174-179

18. Kusari J, Kenner KA, Suh K-I, Hill DE, Henry RR (1994) Skeletal muscle protein tyrosine phosphatase activity and tyrosine phosphatase $1 \mathrm{~B}$ protein content are associated with insulin action and resistance. J Clin Invest 93: 11561162

19. Zucker LM, Antoniades HN (1972) Insulin and obesity in the Zucker genetically obese "fatty" rat. Endocrinology 90: $1320-1330$

20. Becker-Zimmerman K, Berger M, Berchtold P, Gries FA, Herberg L, Schwenen M (1982) Treadmill training improves intravenous glucose tolerance and insulin sensitivity in fatty Zucker rats. Diabetologia 22: 468-474

21. Ionescu E, Sauter JF, Jeanrenaud B (1985) Abnormal oral glucose tolerance in genetically obese (fa/fa) rats. Am J Physiol 248: E500-E506

22. Debant A, Guerre-Millo M, Le Marchand-Brustel Y, Freychet P, Lavau M, Van Obberghen E (1987) Insulin receptor kinase is hyperresponsive in adipocytes of young obese Zucker rats. Am J Physiol 252: E273-E278

23. Häring H, Obermaier B, Ermel B et al (1987) Insulin receptor kinase defects as a possible cause of cellular insulin resistance. Diabete Metab 13: 284-293

24. Bailey CJ (1988) Metformin revisited: its actions and indications for use. Diabet Med 5: 315-320

25. Hother-Nielsen O, Schmitz O, Andersen PH, Beck-Nielsen $H$, Pedersen O (1989) Metformin improves peripheral but not hepatic insulin action in obese patients with type II diabetes. Acta Endocrinol 120: 257-265

26. Galuska D, Zierath J, Thorne A, Sonnenfield T, WallbergHenriksson H (1991) Metformin increases insulin-stimulated glucose transport in insulin-resistant human skeletal muscle. Diabete Metab 17: 159-163

27. Handberg A, Kayser L, Høyer PE, Voldstedlund M, Hansen HP, Vinten J (1993) Metformin ameliorates diabetes but does not normalize the decreased GLUT 4 content in skeletal muscle of obese (fa/fa) Zucker rats. Diabetologia 36: $481-486$ 
28. Bradford M (1976) A rapid and sensitive method for the quantitation of microgram quantities of protein utilizing the principle protein dye bonding. Anal Biochem 72: 248254

29. Prigent SA, Stanley KK, Siddle K (1990) Identification of epitopes on the human insulin receptor reacting with rabbit polyclonal antisera and mouse monoclonal antibodies. $\mathrm{J}$ Biol Chem 265: 9970-9977

30. Ganderton RH, Stanley KK, Field CE, Coghlan MP, Soos MA, Siddle K (1992) A monoclonal anti-peptide antibody reacting with the insulin receptor $\beta$-subunit. Biochem $\mathrm{J}$ 288: 195-205

31. Swarup G, Speeg KV, Cohen S, Garbers DL (1982) Phosphotyrosyl-protein phosphatase of TCRC-2 cells. J Biol Chem 257: 7298-7301

32. Shen S-H, Bastien L, Posner BI, Chrétien P (1991) A protein-tyrosine phosphatase with sequence similarity to the $\mathrm{SH} 2$ domain of the protein-tyrosine kinases. Nature 352 : 736-739

33. Sun XJ, Crimmins DL, Myers MG, Miralpeix M, White MF (1993) Pleiotropic insulin signals are engaged by multisite phosphorylation of IRS-1. Mol Cell Biol 12: 7418-7428

34. Kuhné MR, Pawson T, Lienhard GE, Feng G-S (1993) The insulin receptor substrate 1 associates with the SH2-con- taining phosphotyrosine phosphatase Syp. J Biol Chem 268: 11479-11481

35. Lorch E (1971) Inhibition of intestinal absorption and improvement of oral glucose tolerance by biguanides in the normal and in the streptozotocin-diabetic rat. Diabetologia 7: $195-203$

36. Jackson RA, Hawa MI, Jaspan JB et al. (1987) Mechanism of metformin action in non-insulin-dependent diabetes. Diabetes 36: 632-640

37. Meyer F, Ipaktchi M, Clauser H (1967) Specific inhibition of gluconeogenesis by biguanides. Nature (London) 213: 203-204

38. Fantus IG, Brosseau R (1986) Mechanism of action of metformin: insulin receptor and post-receptor effects in vitro and in vivo. J Clin Endocrinol Metab 54: 95-100

39. Bailey CJ, Puah JA (1986) Effect of metformin on glucose metabolism in mouse soleus muscle. Diabet Metab 12: 212-218

40. Molnar IG, Davidson MB (1988) Metformin has both insulin-like and anti-insulin effects in cultured muscle cells. Clin Res 36: 157A (Abstract) 